\title{
HERCYNIAN EUROPE
}

by

\section{F. Ellenberger and A.L.G. Tamain}

In Upper Palaeozoic times, nearly the whole of southern turope was affected by Hercynian movements which led to the formation of the Variscan folded chains (Variscides). This article describes three major regions of the Variscides: the northern zones, extending from the Variscan front to the Ligerian line, including the axial part; the southern zones - from the Ligerian line to the Alpine foredeep, and the Iberian Meseta of Spain and Portugal.

Tine northern limit of the Variscides - the "Variscan front" can be traced from southwestern Ireland, through southern England, the Boulonnais and the Ruhr, as far as Silesia, where it disappears beneath the Carpathians (Fig. 1). A large part of this area was later affected by the Alpine orogeny. The part that remained outside of the future Alpine mobile zone is what H. Stille called "Meso-Europe".

This quasi-platform, established in late Palaeozoic times, was warped into a pattern of basins and swells from Triassic time onwards. The study and reconstruction of the Variscan orogen is complicated by its consequent fragmentation into isolated "Hercynian massifs" which are anything but homogeneous: they include elements of much earlier deformations (Caledonian, Cadomian, and even older), as well as strictly Hercynian components.

\section{Northern foreland}

North of the Variscan front, the northern (Epicaledonian) foreland is best exposed in Brabant. It has been encountered at depth from boreholes in Holland, Westphalia and the neighbouring regions. This margin of the North European platform is covered by Devonian continental deposits in discontinuous (Old Red Sandstone) basins, or by a thin postEifelian (early Middle Devonian) cover overlain by neritic carbonate sediments in the Lower Carboniferous (Dinantian), and by paralic molassic deposits in the Namurian and Westphalian (productive Coal Measures).

The whole of the Epicaledonian foreland suffered the after effects of Variscan folding, which took the form of swelling and tilting movements (of variable intensity), and of block faulting.

\section{Subvariscan zone and Variscan front}

The Subvariscan zone (Subvariscan foredeep or Westphalian zone), the most external unit of the Variscan, appeared in the Upper Carboniferous at the southern margin of the Epicaledonian foreland as the latter subsided. Together with the Rheno-Hercynian zone, it constitutes the externides of the Meso-European Variscides, though it is distinguished from this zone by its paralic molassic sedimentation and its

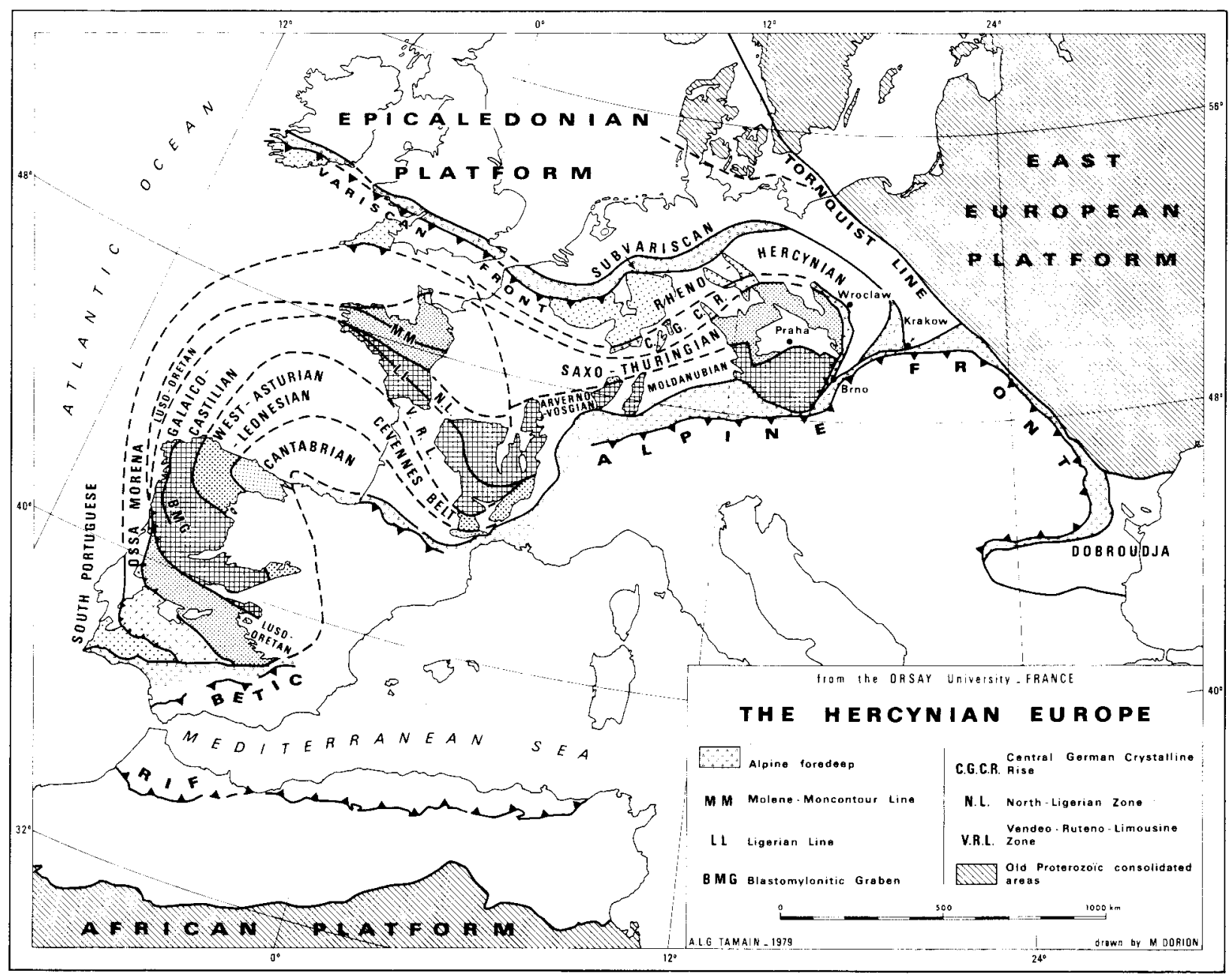

Figure 1. Map showing major zones of the Hercynian in Europe. 
productive Coal Measures, folded during Asturian tectonism.

A belt of major late-phase tangential fractures, cutting folds already formed, emphasizes the Variscan front from Wales to the Rhine. For example, the Ardennes have overthrust the Franco-Belgian coal basin along the "Faille du Midi" (Condroz thrust or Eifel fault). Similarly, in southernmost Wales and the Mendip Hills, Devonian and Dinantian deposits have overthrust the Coal Measures. The amplitude of the total tangential compression is variable, the cumulative shearing movement of the thrusts exceeding $40 \mathrm{~km}$ in the Namur syncline, and $15-25 \mathrm{~km}$ near Bristol.

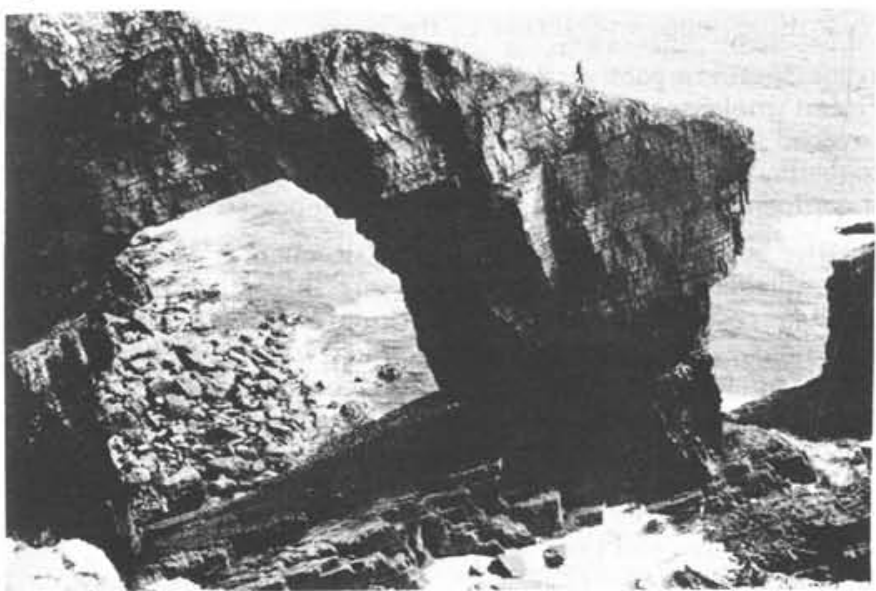

The "Green Bridge of Wales" - a natural arch eroded in Lower Carboniferous limestones, Castlemartin, Pembrokeshire, Wales. (Photo courtesy National Museum of Wales)

\section{Northern Zones}

\section{Rheno-Hercynian zone}

The Rheno-Hercynian zone comprises Cornwall and Devon, the Ardennes (with the Dinant and Namur basins), the Rhine schistose massif, the Harz and the Flechtingen-Rosslau massif. Its continuation is in the Nisky Jesenik mountains of Sudetenland. According to Aubouin (1965), the following may be distinguished in it: an external miogeosynclinal trough (Brocken, Sauerland, Stavelot, Eifel, Dinant, Rocroi); a central miogeanticlinal ridge (Siegerland); and an internal eugeosynclinal trough (Taunus, Hunsrück).

\section{Stratigraphy}

Devonian sediments generally lie discordantly on the Cambro-Silurian substratum. They are mainly shaly or sandy and may be very thick. In Upper Devonian, Hercynian mobilization was marked by the formation of carbonate swells and troughs with argillo-siliceous sedimentation. During Famennian time, in the southern Rhine schistose massif and the Harz, fine clastic sedimentation predominated, but the presence of conglomerates and flyschoid deposits of material derived from the Central German Crystalline Ridge further to the south indicates precocious movements. At the close of the Devonian, slight uplift and regression affected the margins of the Rheno-Hercynian zone and its component units (see Table for European stage names).

On the eastern edge of the Rhine schistose massif and the Harz, flysch sedimentation which began at the end of the Devonian with deposition of the first greywackes, culminated in the formation of the Viséan "Culm-Greywacke"; the latter included terrigenous deposits from the Central German Crystalline Ridge which accumulated in a "Culm trench" that gradually migrated NNW.

Sedimentation in the zone during the Dinantian was very thick, characterized by sequential displacement, with time, of the basins and then of the folding toward the northern foreland. Thus, Tournaisian sedimentation transgressed northward in the external zone, was affected by slight tectonic instability in the Viséan, and, in Namurian times, was again invaded by a nor thwestward transgression.

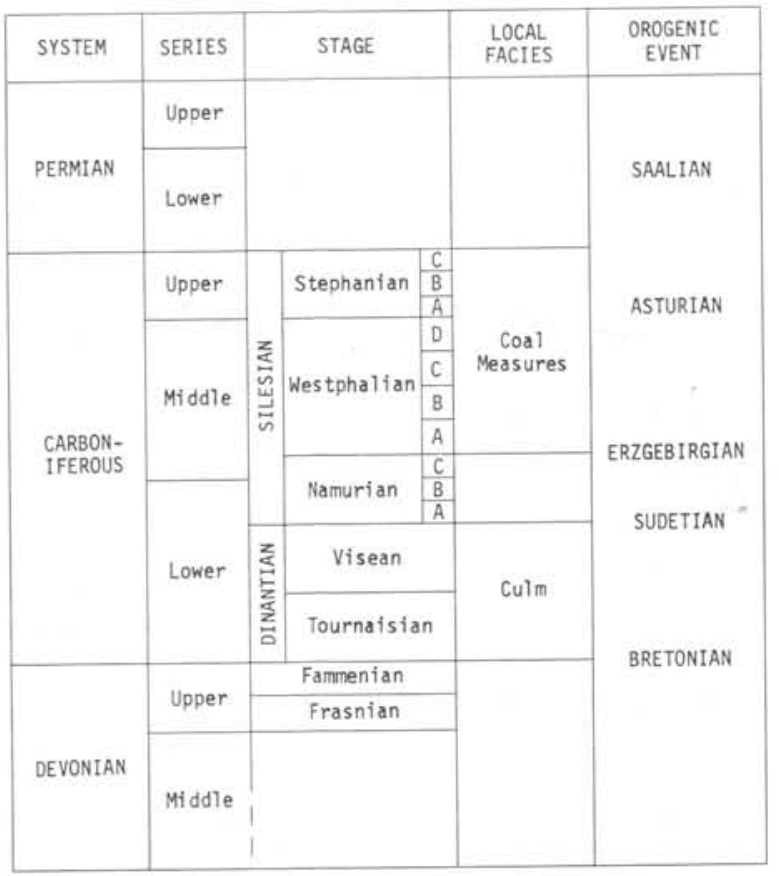

Table showing stage names, facies and orogenic events commonly referred to in the Hercynian of Europe.

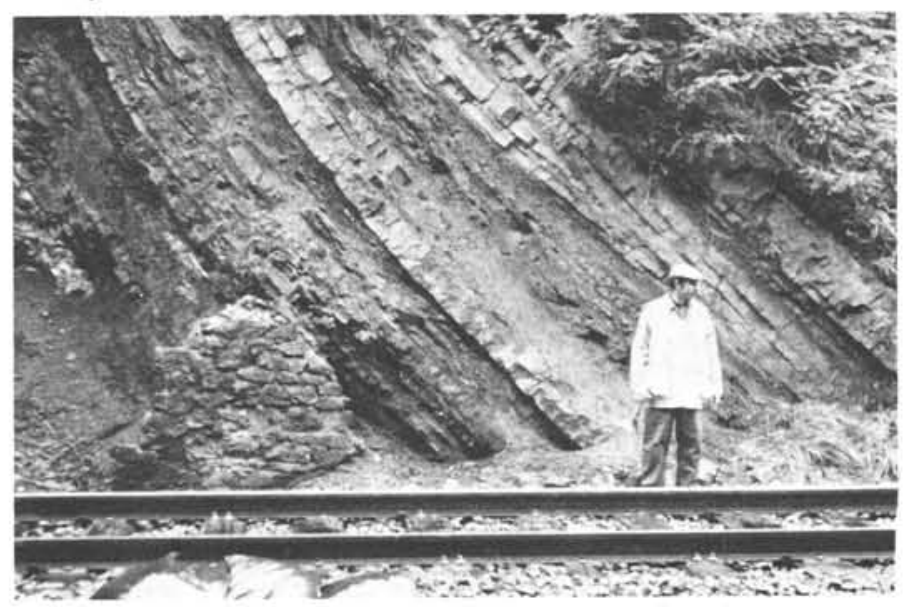

Carboniferous (Tournaisian) Culm comprising black shale, oil shale, and black quartzite, Maine, France. (Photo courtesy W.H. Poole)

In SW England, mid-Devonian to Dinantian sedimentation also reveals a certain degree of tectonic instability. Flysch in southern Cornwall grade into reef limestones and spilites in south Devon, to marine shales further north, and finally to deltaic and littoral deposits in South Wales. Sites of deposition are small basins or trenches.

In Devonshire, the onset of orogenic activity in the Namurian was heralded by deltaic and thick distal turbidite deposits. Folding began at depth shortly before Namurian time, directly above the Cornish batholith as it started to ascend. In Westphalian time, the turbidite basin was filling up, sedimentation became coarser and coarser, tectonic deformation intensified, and the ascent of the Cornish batholith resulted in a geanticlinal uplift with paralic sedimentation in north Devon.

Late Devonian and Dinantian vulcanism, similar to presentday continental basalts, had a distinct bimodal (basic and acid) chemistry. Alkaline, rich in $\mathrm{Ti}$, it is represented by a characteristic spilite-keratophyre association in the Harz, SW England, and the Rhine schistose massif (which also includes spilitic diabases, picrites and rare ultrabasic cumulates with olivine). 
Variscan folding migrated from basins already filled to those which were in the course of being filled. This progression began in the Viséan in the southern part of the zone, affecting the rest of the area during the major deformation (Asturian phase) which took place between the Westphalian C and the end of Stephanian.

Tectonics are simple in outline but complex in detail. For example, numerous isoclinal folds overturned to the NNW, accompanied by a generalized slaty cleavage, were cut by minor late-phase thrusts. Regional metamorphism is either lacking or weak (Ardennes, eastern Harz, Hunsrück). The only known granites are post-tectonic, late Carboniferous, and intrude the country rock, as in the Harz (Brocken) and Cornwall (where they are tin-bearing).

From a geophysical point of view, the Rheno-Hercynian zone appears as a trench filled with up to $10000 \mathrm{~m}$ of Palaeozoic sediments (in the Dinant basin), apparently situated above an area of crustal thinning.

\section{Central German Crystalline Rise}

The Central German Crystalline Rise (or Ridge) includes highly metamorphosed Precambrian and pre-Hercynian formations caught up in the Hercynian deformation. Outcrops are restricted to the small Ruhla-Brotterode (NW Thuringia), Spessart and Odenwald massifs. Everywhere else it is buried either beneath the molasse of the mid-Carboniferous internal trough that forms the Saar coal basin, or beneath younger, Mesozoic cover. On the south it is bordered by the narrow Schladerbach-Doberlug synclinorium.

Uplift started in the Upper Devonian, reaching its peak during the Viséan. Deformation led to overturning; in the Upper Viséan, the region became a synclinorium in which discordant "post-tectonic" molasses were then deposited, accompanied by andesitic extrusions.

Authors generally interpolate the ridge westwards, beneath the Paris Basin, reappearing in the western Channel as the gneissic basement of the Pays de Bray and the coast of Cornwall (Start Point, the Dodman, the Lizard), where it is bounded to the north by a great overthrusting suture. Its southern limit cuts the corner of the Cotentin peninsula (with the $2500 \mathrm{Ma}$ old granitic gneisses of the Nez-de-Jobourg, Omonville and the Trégorrois).

The ridge appears to extend eastward from Berlin, describing an arc (convex to the north) which disappears near Wroclaw.

\section{Saxo-Thuringian zone}

In Central Europe, the Saxo-Thuringian zone is made up of the following units (from NW to SE): an external region comprising the Schwarzburg-Leipzig-Lausitz anticlinorium; the central Saxon synclinorium, including the two brachyanticlinorial structures of the Berga and the Granulitgebirge, the Münchberg gneissic massif, and the two intermediate Saxon Wildenfels and Frankenberg massifs; and an internal region which includes the Fichtelgebirge and the Erzgebirge anticlinorium.

\section{Stratigraphy}

The zone experienced a long sedimentary and magmatic history in the Proterozoic and Lower Palaeozoic. Hercynian mobilization began in the Upper Devonian with greywacke sedimentation in the northern part and thin neritic sedimentation in the south. The earliest neritic deposits are covered by unconformable transgressive neritic limestones of Dinantian age (in the Erzgebirge). An extensive late Devonian magmatic event occurred in certain tectonically unstable sectors of the external region (such as a few of the basic and ultrabasic intrusions around the Erzgebirge), and was accompanied by Lahn-Dill-type mineralization. This was followed by flysch deposition (greywacke, conglomerate and limestone). Palaeogeographic units retained their positions throughout the zone and did not migrate as in the RhenoHercynian zone.
The main phase of folding was early Sudetic (early to middle Viséan) to Erzgebirgian. It was accompanied by a general metamorphism, weak or absent in the north, but more intense in the south (Erzgebirge, Fichtelgebirge), and by well marked synmetamorphic deformation, including thrusts. In the central Saxon synclinorium, the mesozonal crystalline basement is thrust over Palaeozoic (including Dinantian) formations.

There is, however, no definite evidence for or against the suggestion that the Münchberg massif is a fragment of a vast crystalline nappe overthrust to the north.

In the southern part of the central Saxon synclinorium, Upper Viséan molasses were folded by Erzgebirgian movements, covered unconformably by molassic Westphalian B-C deposits, eroded, and, following Saalian movements, sealed by unconformable, transgressive Permian deposits.

Further south, the onion-scale gneissic cupolas of the Erzgebirge display folds of the Variscan infrastructure, which possibly resulted from the reworking of Cadomian granitic intrusions. The main phase of folding was followed by acid plutonism (with high original metal content), which reached its peak in the Upper Carboniferous. This region experienced a "subsequent" vulcanism during a period of over 60 million years, extending from the main (Asturian) phase to the midPermian (Saalian). This intermediate-to-acid vulcanism was located at the junctions of major fractures descending into the upper mantle.

\section{Extension of zone}

Eastward (beyond the "Elbe lineation"), the Saxo-Thuringian zone continues in the western branch of the Sudeten mountains, where it differs little from the type region in Saxony and Thuringia. Westward, the zone continues into the northern fringe of the Black Forest and the northern Vosges (north of a line from Saint-Dié to Sélestat).

It is common to continue this zone westward beyond the Vosges, beneath the southern half of the Paris Basin, as far as the Armorican massif. Although there are no outcrops for $500 \mathrm{~km}$, this interpolation is supported by numerous lithofacial and biostratigraphic correlations, not only of Hercynian but also of Caledonian age. For example, a socalled external limestone belt (of Lower Cambrian and early Middle Cambrian age) with stromatolites, Archaeocyathan colonies and associated acid vulcanism (Doré et al., 1977), stretched from Breslau through Lusatia and the Fichtelgebirge as far as the Cotentin, and from there to the Ossa Morena (Cordoba) in the southern Iberian Meseta.

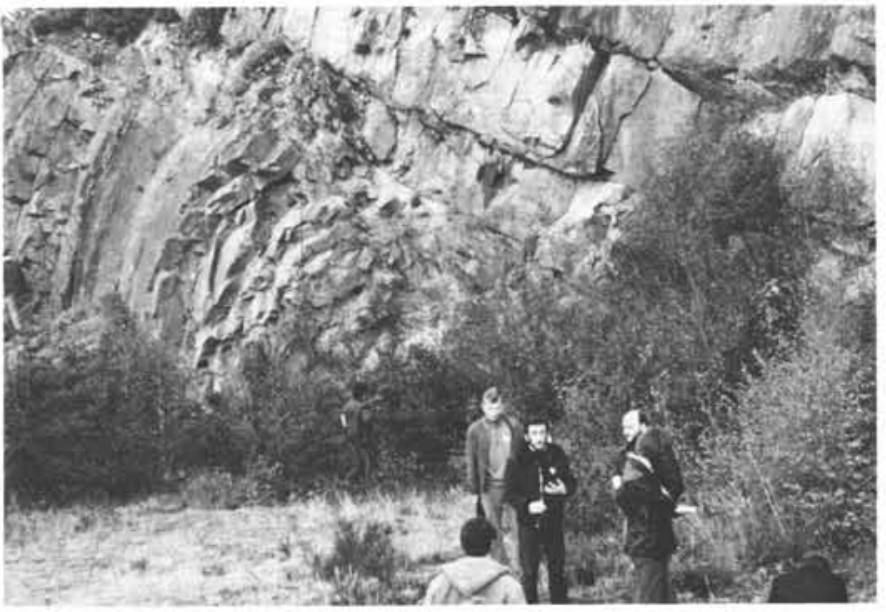

Well bedded late Cambrian to Tremadocian conglomerate and red shale lying with angular unconformity on nearly vertical Brioverian siltstone and grit of Hadrynian age in the Armorican massif, $30 \mathrm{~km}$ west of Rennes, France. (Photo courtesy W.H. Poole) 
In Normandy and north Britanny, the zone is characterized particularly by the late Cadomian acid rhomboidal plutonic block of the Mancellia. It extends also into central Armorica, where it is cut by the major E-W "MolèneMoncontour lineation" which can be traced for over $350 \mathrm{~km}$ (Fig. 1). It is a major crush zone, with elements of basement, packages of basic and ultrabasic rocks of oceanic affinities (Belle-Isle-en-Terre), Hercynian tectonic slices, and Variscan leucogranites (Cogné and Jest, 1977). The central Armorican province, limited to the south by a great linear fracture - the Ligerian line - is underlain by early Carboniferous sediments and volcanics.

In the Laval Basin, for example, a Tournaisian shaly and conglomeratic series includes acid subaerial volcanics with rhyolitic ignimbrites and keratophyres, succeeded in the Lower to Middle Viséan by outpourings of acid tuffs. Further west, in the Chateaulin basin, Tournaisian diabase of tholeiitic basalt composition was extruded, along with a spilitekeratophyre series which included lava flows, pyroclastics, and a siliceous Fe-Mn facies.

\section{Moldanubian zone}

This zone constitutes the axial portion of the central European Variscides. It corresponds not so much to an inert intramontane block ("Zwischengebirge") as to an eugeanticlinal zone whose deformation was accompanied by lowpressure/high-temperature metamorphism, and by the emplacement of granite magmas.

The zone was first defined in the central and southern Bohemian massif, where the Precambrian basement consists of an early (Moldanubian) cycle which ended at about 1000 $\mathrm{Ma}$, and a later (Algonkian or Brioverian) cycle of the Cadomian orogeny with amphibolite-facies metamorphism. To the north, the highly fossiliferous and scarcely folded shales of the Palaeozoic, rest unconformably on the "Algonkian" substratum.

The Hercynian cover is thin, with neritic shelf deposits (locally as old as late Devonian), Breton emersion, unconformable Dinantian deposits of Culm facies, and very local but intense trachy-andesitic vulcanism and back-deep granodioritic instrusions. After a mid-Carboniferous interval, freshwater (lacustrine) deposits were laid down unconformably in Upper Carboniferous times in narrow, fault-bounded basins.

Variscan tectonism comprised Breton, Sudetic, Erzgebirgian and Saalian movements, which terminated at the end of the Permian with a crustal consolidation, forming a typical Epivariscan platform or shelf. Regional metamorphism reached only the greenschist facies.

To the southeast, the Moldanubian zone overrides the Moravian zone, the latter forming part of a larger ENE-WSW trending complex transverse to the main Variscan lines; it is thought (Andrusov, 1976) to be mainly Rheno-Hercynian. The Saxo-Thuringian zone is pinched in further to the northwest, where it disappears progressively beneath the Moravian thrust (Fig. 1).

The Moldanubian zone extends westward as the substratum of Bavaria, the Black Forest (of which it forms nearly the whole), the central and southern Vosges, and then as the north central region of the Massif Central (Arverno-Vosges massif). Its northern limit in France is traced by a band of leucogranites running from the Vosges to the Morvan, from where it joins the southern Armorican shear zone as far as the Pointe-du-Raz on the coast.

In the Massif Central, the zone includes Barrovian cordierite gneisses and anatexites ( $\mathrm{Rb} / \mathrm{Sr}$ ages of 670-650 Ma) with relict paragneisses of granulites, micaschists and gneisses. These are overlain unconformably by Upper Devonian sediments of Culm facies and albitite vulcanics. They in turn are covered by transgressive early Viséan neritic marine deposits and late Viséan ignimbritic volcanism (anthracite-bearing tuffs). Biotite granites were intruded from the Devonian to

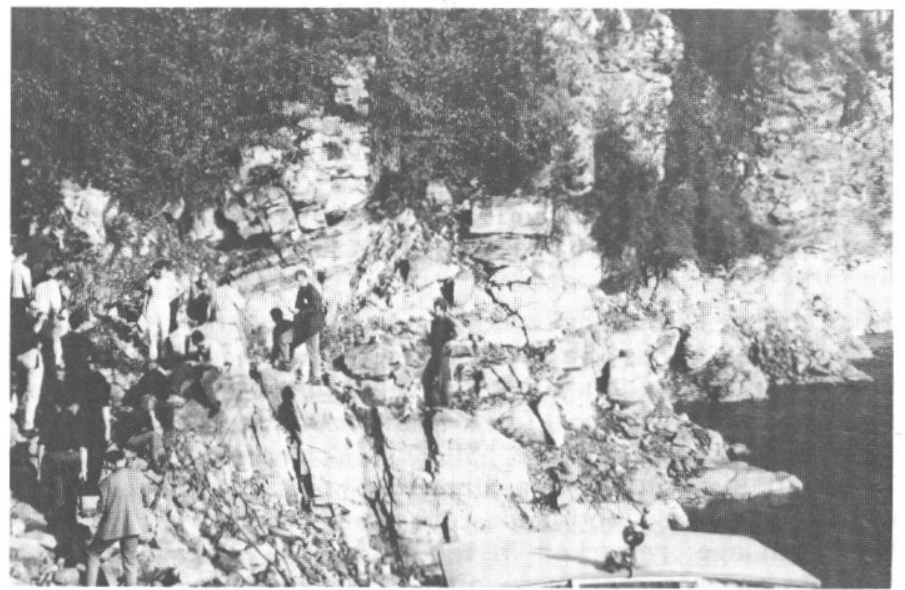

Highly granitized Precambrian (Gföhl) gneisses which were possibly affected by Hercynian movements in the Moldanubicum of the Bohemian massif, SW of Brno, Czechoslovakia. (Photo courtesy L.P. Tremblay)

the Westphalian, while the biotite-cordierite granite at Guéret is considered to be a late palingenesis of the anatexites.

The Moldanubian zone is thought to reappear in the Armorican massif in the North Ligerian zone (Fig. 1). It is bounded to the north by a lineation running from Pointe-duRaz to Angers, and to the south by the great "Ligerian Lineation" (or the southern Armorican crush zone). This line is a major intracratonic suture, characterized by sheared strata of the Rutheno-Limousin zone through overthrusting by the Moldanubian both in pre-Westphalian and in post Stephanian times. In addition, it is the site for post Dinantian leucogranites generated by crustal anatexis.

In this region, the Cadomian basement is made up of Brioverian metasediments associated with basic and ultrabasic rocks: serpentinized dunites (with $\mathrm{Cr}-\mathrm{Pt}$ ), metagabbros (with ilmenite-magnetite $+\mathrm{Ni}$ ), greenschists with pillow lavas, tuffs and siliceous schists. The formations are metamorphosed in the west but not in the east. The basement displays nappes and is granitized. Radiometrically determined ages of $550 \mathrm{Ma}$ suggest a Lower Palaeozoic age for the main tectono-metamorphic development of parts of this basement. It is covered by discontinuous and incomplete Palaeozoic epicontinental deposits, including transgressive Middle Cambrian to early Ordovician deposits.

The region has remained above sea level practically since the Lower Devonian. Hercynian granitization played an important role, especially in exploiting lineations. A few small Stephanian coal basins also developed in the fault-bounded basins related to these fracture-lines.

The striking Hercynian fracture network is syn-kinematic at least in part (Tamain, 1975, and Rossi and Tamain, 1975), and certain lineations are metallogenetic "vectors" (for example, the Pointe-du-Raz to Angers for gold and lead, its southern Chalonnes satellite for lead). The same applies to certain granite-complex margins active at that time (such as Mortagen for uranium).

\section{Southern Zones}

The southern branch of the Variscides is best represented in southern France, though it is still little known. The following summary deals only with the parts that were not caught up in the Alpine orogeny.

\section{Vendee-Rutheno-Limousin zone}

In the Massif Central, this zone is characterized by a predominance of rhythmic sedimentation, abundance of basic volcanics, thick stratiform quartzo-feldspathic formations (which may represent the lowest part of the basement-cover) and, towards the top, by an epischistose series (with micro- 
faunas of Ordovician, Silurian and early Devonian ages).

In Rouergue, the Barrovian metamorphism appears to be Caledonian or Reussian (430-360 Ma, Autran, 1978). This metamorphism is more or less obliterated by a second, Hercynian metamorphism, apparently that of the higher epischists and associated with either a Breton or Sudetic phase. In the Westphalian, the Limousin (already above sea level in the Dinantian), became the southwestern margin of the Arvernian nucleus.

This complex extends northwestward beneath the Poitou threshold as far as the south Ligerian province to form the Vendée-Limousin zone. The evolution of Vendée is not fundamentally different from that of the preceding region: schistose Ordovician and Silurian formations, a Lower Devonian hiatus, Givetian limestone reefs, another Upper Devonian hiatus, red sandstones and shales of possible Dinantian age, reworked in the Namurian. The Namurian deposits are not metamorphosed, but were deformed during an intra-Westphalian phase of folding.

This province, in the region of Saint-Nazaire, is characterized by a Cadomian magmatism and by a Siluro-Brioverian sedimentary complex (with basic and ultrabasic rocks of oceanic affinities). In addition, there are Cadomian or thogneisses, cut by acid plutonic rocks dated at $460 \mathrm{Ma}$. The province is also characterized by a complicated tectonometamorphic development: on the one hand, there are migmatites and anatexic granites of $370 \mathrm{Ma}$; on the other, there are jadeite-lawsonite glaucophanites (symptomatic of a highpressure/low temperature metamorphism) dated at 420-370 Ma.

\section{Cevennes belt}

The Precambrian history of the Cévennes belt in southern France (Fig. 1) is similar to that of the preceding zone. No Caledonian orogenic deformation can be detected in the northern Cévennes, aside from slight Middle Ordovician uplift in the Montagne Noire. In the southern region, early Carboniferous (Culm facies) deposits overlie Silurian and Devonian sediments.

The main phase of the Variscan orogeny is Asturian and is presumed to be early Stephanian. It is manifested in the north of the Montagne Noire and the Albigeois as recumbent folds with the development of an epizonal regional metamorphism. In the rest of the Montagne Noire and the Mouthoumet, it appears as a splendid development of nappes, in many cases overturned southward or southeastward (the vergence of folds and imbrication in the northern part is reversed).

\section{Iberian Meseta}

An extensive area of Variscides, the Iberian Meseta for Hesperic massif/the Hersperides) of Portugal and Spain can be subdivided into six zones.

\section{South Portuguese zone}

The South Portuguese zone is characterized by:

- a late Devonian to Carboniferous sedimentation with vulcanism and associated sulphide mineralization, followed by accumulation of a very thick flysch series (Culm facies) in the late Viséan, which continued up to the Westphalian A in the southwest;

migration of the Variscan palaeogeography and tectogenesis from SW to NE, followed by a major, postNamurian (to post-Westphalian A?), pre-Westphalian D phase of folding, producing folds of SW to SSW vergence, along with shearing and thrusting to the SSW and, in places, weak metamorphism;

- Late Carboniferous (Coal Measures) deposition on the northwestern fringe;

- a late phase, post-tectonic plutonism with subvolcanic facies on the northeastern fringe, and very extensive metallogenesis, giving rise to the famous Huelva-Rio Tinto-Aljustrel pyrite belt.

This zone has been correlated with the Rheno-Hercynian zone, especially with the segment in SW Ireland.

\section{Ossa Morena}

The Precambrian of the Ossa Morena is characterized by a Cadomian substratum with large overthrusts. Early Palaeozoic carbonate deposition in the Cambrian became restricted to the south in the Ordovician, and was of variable thickness in the Silurian. It was overlain by Devonian epicontinental deposits, which were in turn followed by Dinantian and early Namurian flysch, restricted to trenches and paralic molasses with productive Coal Measures.

The zone was strongly deformed during post-early Namurian to pre-Westphalian D, producing folds with WNW-ESE axes and accompanied by a low to intermediate pressure metamorphism and a polyphase acid magmatism, with syntectonic, late-phase tectonic or post-tectonic phases.

The Ossa Morena is bounded to the north and nor theast by the "Cordoba-Badajoz lineation" (which includes an alignment of basic and ultrabasic rocks of Tournaisian to early Viséan age); it is bordered on the north by a large polyphase calc-alkaline granite batholith. The zone has been correlated with the Central German Crystalline Rise.

\section{Luso-Oretan zone}

The Luso-Oretan (or Luso-Alcudian) zone is characterized by: - a metasedimentary substratum of Cadomian age;

- deposition that was very thin and local in the Cambrian (Dore's internal carbonate belt), complete and thick in the Ordovician (with Taconic glaciation at the top), and epicontinental in the Silurian and Devonian;

- Sardian, Taconic and Reussian epeirogenic movements;

- continuous late Devonian and Dinantian (to early Namurian?) deposition with Culm facies in the Upper Viséan;

- deposition of Coal Measures with acid aerial vulcanism in the Stephanian and Autunian in the narrow Puertollano fault-bounded basin;

- a major post-Viséan to post-early Namurian phase of folding, producing WNW-ESE folds of SSW vergence, later sheared into numerous slices and accompanied in places by low-pressure metamorphism;

- a late-phase calc-alkaline granodioritic to granitic plutonism, well developed in Extremadura; and

- varied metallogenesis, pneumatolytic to hypothermal (with $\mathrm{Sn}$ and $\mathrm{W}$ ) and vein-type mesothermal (with $\mathrm{Cu}, \mathrm{Pb}, \mathrm{Pb}-\mathrm{Ag}$ ).

This zone may be correlated with the Saxo-Thuringian as well as with the Norman-north Breton (in part) and mid-Breton provinces.

\section{Galaico-Castilian zone}

The Galäico-Castilian zone provides the crystalline core of the Iberian structure. Cadomian basement, with its Braganza and Morais nappes, outcrops in a broad area and is covered unconformably by transgressive Ordovician followed by Silurian and early Devonian sediments. Coal Measures are confined to narrow internal basins.

Variscan tectonism is polyphase, its main phase not well dated (post-early Devonian and pre-Westphalian D, perhaps prior to $300 \mathrm{Ma}$ ). It produced recumbent folds of great amplitude, involving the Precambrian basement as well as narrow anticlines and synclines. It is accompanied by a metamorphism ranging from low pressure to Barrovian. Plutonism is of many facies and in phases that are synmetamorphic, syntectonic-to-late tectonic and late-to-post-tectonic.

The zone includes a broad suture, the "Blastomylonitic Graben" (Fig. 1), characterized by the presence of alkaline to hyper-alkaline acid plutons (which may originally have been ring structures, later metamorphosed).

\section{West Asturian-Leonesian zone}

This zone includes a partly metamorphic Precambrian basement (in the west) and is characterized by thick Cambrian, Ordovician and Silurian deposits, and thin early Devonian and pre-Stephanian Carboniferous deposits, with unconformable 
Westphalian B-C Coal Measures.

Tectonism is polyphase. The major phase generated large recumbent folds verging toward the east and accompanied by low pressure metamorphism decreasing in grade eastward, apparently older than $310 \mathrm{Ma}$. The second phase sliced through the preceding structures and caused them to be overthrust eastward. The third phase, probably of midWestphalian age (pre-Stephanian B-C), refolded these last structures with reverse thrusting effects. There was also polyphase acid plutonism, decreasing in volume from west to east.

The zone has been correlated with the Cévennes belt.

\section{Cantabric zone}

The Cantabric zone is characterized by:

- unequally developed Cambrian, Ordovician and Silurian deposition, incomplete in many places and locally absent;

thick Devonian deposition, with Asturia-Leon facies carbonates in the SW and Palencian pelagic facies in the SE;

thick late Devonian to Carboniferous deposition, noteworthy for its calcareous Namurian flysch and its Westphalian paralic molasse ( $5000 \mathrm{~m}$ in the central coal basin); and

- continental Stephanian B-C deposits.

Tectonism is polyphase, the main "Palencian" deformation having produced overthrust sheets and imbricate structures. These were later refolded in an arcuate system of folds with vertical axial planes. A "Leonian" (intra-Westphalian D) phase produced a second system of radiating folds, with an Asturian compression phase and, finally, a late Saalian phase. Regional metamorphism is absent or weak. There is very minor late-phase to post-tectonic plutonism.

The zone has been correlated with the southern fringe of the Montagne Noire and the Mouthoumet.

\section{Conclusion}

For authors presenting ideas of the Variscan of Meso-Europe, a major turning point was marked by the preparation and publication in 1962 of the International Tectonic Map of Europe at 1:2 500 000: it provided both a synthesis of existing knowledge and an excellent working tool. It is to J. Aubouin, however, that one owes the first overall modern vision of the Variscides, for he was the first to take all the characteristics of their evolution into account.

The existence of a vast belt appearing between the ancient platforms of Africa and eastern Europe can now be established, and, within it, the general form of the great lithostructural zones and of the northern Variscan front, describing a vast double loop. There is a western, Ibero-Armorican loop, of northwestern convexity, with its axis formed by the Pyrenees, and an eastern, Moravo-Silesian loop, with northeastern convexity. This general zonation is more or less retained in the whole of Meso-Europe, in spite of reduction in width (extensive, in some places) of one or another internal zone.

\section{ABOUT THE AUTHORS:}

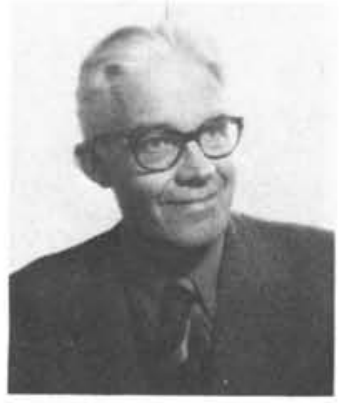

Professor of Structural Geology at the University of ParisSud-Orsay since 1962, François Ellenberger, Dr. ès Sc., was President of the Geological Society of France in 1972. He is currently President of the French Committee for the History of Geology (which he founded in 1976) and an honorary member of the Geological Society of London.
Authors have often emphasized the bipolar symmetry of the Variscan belt, and the "centrifugal" propagation of the orogeny. We must point out, however, that in the LusoOretan zone (for example), assemblages of Erzgebirgian slices that had originally been thrust to the south and southwest were later moved to the north and nor theast along the great mid-Westphalian thrusts. Thus, in speaking of orogenic polarity in such regions, it is important only to compare the vergence and/or displacement of units of the same age, or at least belonging to the same phase of deformation.

Certain characteristics are peculiar to the Variscan chain. These include: the very weak representation (by volume) of ophiolites; the appearance of a thermal crisis which, in the axial part of the chain, gives exceptionally high thermal gradients in the major phase, represented by low pressure metamorphism imprinted on an earlier Barrovian metamorphism; the control exerted throughout the early, main and late stages of tectonism by an impressive network of strikeslip faults on the geometry of the palaeogeographic units, tectonism, the emplacement of the magmas, and the localizing of the metalliferous mineralization.

Hercynian tectonism seems clearly to have been superimposed on a structural fabric, the framework of which had been formed by the end of the Cadomian. The Variscan belt is in an essentially ensialic framework where the continental crust is rarely older than 700-600 Ma.

\section{References}

Aubouin, J., 1965, Geosynclines: Elsevier Pub. Co., Amsterdam, 302 p.

Andrusov, D., 1976, Croquis tectonique des Variscides d'Europe centrale: Soc. Géol. Fr., Bull., 18/5, p. 196-197.

Autran, A., 1978, Synthèse provisoire des évènements orogéniques calédoniens en France, in Tozer, E.T. and Schenk, P.E., Caledonian-Appalachian Orogen of the North Atlantic Region: Geol. Soc. Canada, Paper 78-13, p. 159-175.

Cogné, J. and Jest, C., 1977, La chaîne Hercynienne ouestEuropéene. Correspond-elle à un orogène par collision ?: Cent. Natl. Rech. Sci., Colloq. Int., 268, v. 2, p. 111-129.

Doré, F., Larrsonneur, C., Juignet, P., Pareyn, C., Rioult, M.and Pomerol, C., 1977, Normandie: Guides géologiques régionaux, Masson, Paris, v. 19, 207 p.

Rossi, P. and Tamain, G., 1975, Tectonique profonde et minéralisations Varisques dans le sud et l'ouest de la Meseta Ibérique: Congr. Natl. Soc. Savantes, Sect. Sci., C.R., 99, fasc. 1, géologie, p. 109-118.

Tamain, G., 1975, Megatectonique lineaments et fracturation profonde de la Meseta Ibérique: Rév. Géogr. Phys. Géol. Dyn., v. 17, 4, p. 375-391.

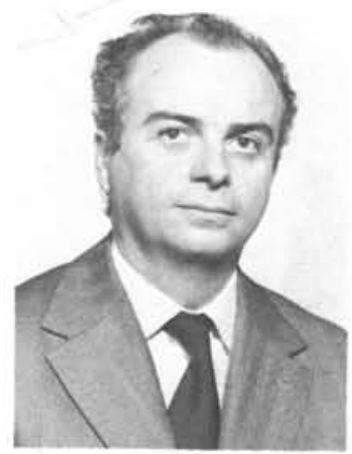

A specialist in studies of the Iberian Meseta, Dr. A.L. Guy Tamain is a research investigator with CNRS (National Scientific Research Centre) of France. A graduate of Orsay University, he has also served in Costa Rica as a consultant for UNESCO in the area of economic geology. Recently, his research interests have concentrated on remote sensing as applied to structural geology, continental fractures and mineral exploration (particularly in Spain, Portugal, North Africa and Central America). 